\title{
TOPOLOGY OF ${ }^{28}$ Si FRAGMENTATION AT DIFFERENT ENERGIES
}

\author{
M. S. El-Nagdy ${ }^{1}$, A. Abdelsalam ${ }^{2}$, B. M. Badawy ${ }^{3}$, A. Algaood ${ }^{4}$ \\ ${ }^{1}$ Physics Department, Faculty of Science, Helwan University, Helwan, Egypt \\ ${ }^{2}$ Physics Department, Faculty of Science Cairo University, Giza, Egypt \\ ${ }^{3}$ Reactor Physics Department, Nuclear Research Center, Atomic Energy Authority, Egypt \\ ${ }^{4}$ Physics Department, Faculty of Science, Amran University, Amran, Yemen \\ Email: he_cairo@yahoo.com
}

(Received July 20, 2012)

\begin{abstract}
This paper presents the projectile fragments emerged from non-central events of $3.7 \mathrm{~A} \mathrm{GeV}$ ${ }^{28} \mathrm{Si}$ collisions in nuclear emulsion. The charges of these fragments were carefully measured and compared with those obtained from $3.7 \mathrm{~A} \mathrm{GeV}{ }^{28} \mathrm{Si}$. The distributions of those charges were given and fitted by the Gaussian shapes. The topology of ${ }^{28} \mathrm{Si}$ fragmentation is given. The dependence of fragmentation process on incident beam energy is studied. The presence of $\alpha$-cluster inside silicon beam is investigated.
\end{abstract}

Key words: ${ }^{28} \mathrm{Si}$ ions, projectile fragmentation, nuclear charge identification.

PACS number(s): 25.75.-q, 25.75.Dw, 25.75.Gz, 25.75.Ld, 25.70.Mn, 25.70.Pq, 41.75.Ak, 41.75.Cn, 29.40.Rg, 07.68. $+\mathrm{m}$

\section{INTRODUCTION}

The heavy ion collision offers a unique opportunity to study the nuclear fragmentation process. Many experimental and phenomenological efforts have been directed at the investigation of projectile fragmentation in relativistic heavy ion collisions. Fragmentation in finite nuclei is a fascinating research subject which has attracted lasting attention for more than thirty years [1-5]. The projectile fragments, $(\mathrm{PFs})$, are strongly collimated in the forward direction [6] with the angle $\theta_{\text {lab }} \leq 3^{\circ}$ at $3.7 \mathrm{~A} \mathrm{GeV}$. In central events this forward cone is empty from any projectile fragments.

This paper is a continuation of our analysis of the interaction of silicon beam with the emulsion target [7-11]. An important aim of this study is to survey the general properties of fragmentation in silicon interactions at two different energies (3.7 and $14.6 \mathrm{~A} \mathrm{GeV})$. An attempt is made to compare the data obtained from the two silicon beams. This yields additional information helpful to understanding the fragmentation process. In addition, silicon beam has 28 nucleons which are equivalent to 7 alpha particles so there is a choice to examine the existence of $\alpha$-clusters inside the beam of silicon.

\section{EXPERIMENTAL DETAILS}

The present experiment was performed in a stack of NIKFI-BR-2 nuclear emulsion of size $20 \mathrm{~cm} \times 10 \mathrm{~cm} \times$ $0.06 \mathrm{~cm}$. These stack tangentially exposed to a ${ }^{28} \mathrm{Si}$ beam with the energy 3.7A GeV at Dubna Synchrophastron. The exposure was made such that the incident beam was almost parallel to the surface of an emulsion pellicle. The inelastic interactions with nuclear emulsion observed for ${ }^{28} \mathrm{Si}$ was detected using the (along the track) method.
The total of 1058 events were analyzed where the respective mean free path was found to be $(9.12 \pm 0.27 \mathrm{~cm})$.

Out of 351 emitted ${ }^{28} \mathrm{Si}$ projectile fragments, 377 events were respectively identified as helium ( $Z=2 \mathrm{PFs})$, and $Z \geq 2$ PFs. These fragments essentially travel with the same speed as that of the parent beam nucleus, and without change in the ionization along their path where followed up to a distance of at least $2 \mathrm{~cm}$ from the interaction centre. The energy of the produced PFs is high enough to distinguish them easily from the target fragments.

In each event, the PFs having charges $Z \geq 2$ are recorded where their charges are identified by $\delta$-ray density measurements [12]. On the other hand, at each interaction point the PFs with $Z=1$ can be well separated by visual inspection of tracks where their ionizations are similar to those of shower ( $~ 30$ grains per 100 micron).

Helium PFs can be easily identified by visual inspection, where their ionizations are similar to those of grey tracks. They are chosen as charge references.

A $\delta$-ray (low-energy electron) which produces a track containing four or more grains has the energy $>15 \mathrm{KeV}$. The number of these $\delta$-rays $\left(N_{\delta}\right)$ ejected by a charged particle of charge $Z$ when it passes through the target material helps to identify the particle producing the track $\left(N_{\delta} \propto Z^{2}\right)$ [13]. At each interaction we measure the $\delta$-ray density of PFs with respect to its primary beam. For this purpose, a calibration line is done by using NIKFI-BR-2 nuclear emulsion irradiated by six primary beams available in our laboratory [*], $\left({ }^{4} \mathrm{He},{ }^{6} \mathrm{Li},{ }^{12} \mathrm{C},{ }^{16} \mathrm{O},{ }^{24} \mathrm{Mg}\right.$, ${ }^{28} \mathrm{Si}$, and ${ }^{32} \mathrm{~S}$ at $3.7 \mathrm{~A} \mathrm{GeV}$ ) from Dubna Synchrophastron. The relationship between the average number of $\delta$-rays per mm for a sample of 40 tracks from each beam and the corresponding charge is shown in Fig. 1. The data are fitted by the linear relation, $N_{\delta}=A Z^{2}+B$, where $A=7.49 \pm 2.16$ and $B=0.50 \pm 0.04$. 


\begin{tabular}{|c|c|c|c|c|c|c|c|c|c|c|c|c|}
\hline \multirow{3}{*}{$\begin{array}{l}N_{h} \\
\text { Energy GeV/A } \\
\text { Ref. }\end{array}$} & \multicolumn{3}{|c|}{$0-1$} & \multicolumn{3}{|c|}{$2-7$} & \multicolumn{3}{|c|}{$\geq 8$} & \multicolumn{3}{|c|}{ Total Sample } \\
\hline & \multirow{2}{*}{$\begin{array}{l}14.6 \\
{[10]}\end{array}$} & \multicolumn{2}{|c|}{3.7} & \multirow{2}{*}{$\begin{array}{l}14.6 \\
{[10]}\end{array}$} & \multicolumn{2}{|c|}{3.7} & \multirow{2}{*}{$\begin{array}{c}14.6 \\
{[10]}\end{array}$} & \multicolumn{2}{|c|}{3.7} & \multirow{2}{*}{$\begin{array}{l}14.6 \\
{[10]}\end{array}$} & \multicolumn{2}{|c|}{3.7} \\
\hline & & $\begin{array}{c}\text { This } \\
\text { Work }\end{array}$ & [14] & & $\begin{array}{c}\text { This } \\
\text { Work }\end{array}$ & [14] & & $\begin{array}{c}\text { This } \\
\text { Work }\end{array}$ & {$[14]$} & & $\begin{array}{l}\text { This } \\
\text { Work }\end{array}$ & {$[14]$} \\
\hline $\mathrm{Si}$ & 40 & 4 & 28 & - & - & 13 & - & - & 6 & 40 & 4 & 47 \\
\hline $\mathrm{Al}+\mathrm{H}$ & 35 & 2 & 27 & 16 & 7 & 37 & 11 & 4 & 6 & 62 & 13 & 70 \\
\hline $\mathrm{Mg}+\mathrm{He}$ & 8 & 5 & 16 & 11 & - & 4 & - & - & 0 & 19 & 5 & 20 \\
\hline $\mathrm{Mg}+2 \mathrm{H}$ & 26 & 4 & 29 & 37 & 13 & 34 & 13 & 4 & 5 & 76 & 21 & 68 \\
\hline $\mathrm{Na}+\mathrm{He}+\mathrm{H}$ & 11 & 15 & 15 & 8 & 11 & 10 & 5 & - & - & 24 & 26 & 25 \\
\hline $\mathrm{Na}+3 \mathrm{H}$ & 6 & 4 & 14 & 48 & 16 & 24 & 19 & 7 & 17 & 73 & 27 & 55 \\
\hline $\mathrm{Ne}+2 \mathrm{He}$ & 8 & 2 & 8 & 5 & - & 2 & - & 2 & 1 & 13 & 4 & 11 \\
\hline $\mathrm{Ne}+\mathrm{He}+2 \mathrm{H}$ & 24 & 11 & 16 & 32 & 17 & 18 & 14 & - & 6 & 70 & 28 & 40 \\
\hline $\mathrm{Ne}+4 \mathrm{H}$ & 8 & 18 & 17 & 27 & 16 & 27 & 8 & 7 & 14 & 43 & 41 & 58 \\
\hline $\mathrm{F}+2 \mathrm{He}+\mathrm{H}$ & 8 & 4 & 7 & 19 & 2 & 10 & - & - & 1 & 27 & 6 & 18 \\
\hline $\mathrm{F}+\mathrm{He}+3 \mathrm{H}$ & 21 & 22 & 13 & 50 & 20 & 16 & 13 & 7 & 10 & 84 & 49 & 39 \\
\hline $\mathrm{F}+5 \mathrm{H}$ & 8 & 11 & 12 & 32 & 15 & 29 & 16 & 4 & 14 & 56 & 30 & 55 \\
\hline $\mathrm{O}+\mathrm{Be}+2 \mathrm{H}$ & - & - & - & - & - & - & 3 & - & - & 3 & - & - \\
\hline $\mathrm{O}+3 \mathrm{He}$ & - & - & 2 & - & 2 & 3 & - & - & 1 & - & 2 & 6 \\
\hline $\mathrm{O}+2 \mathrm{He}+2 \mathrm{H}$ & 6 & - & 12 & 19 & 6 & 7 & 8 & 2 & 2 & 33 & 8 & 21 \\
\hline $\mathrm{O}+\mathrm{He}+4 \mathrm{H}$ & 16 & 36 & 18 & 19 & 31 & 24 & 8 & 4 & 10 & 43 & 71 & 52 \\
\hline $\mathrm{O}+6 \mathrm{H}$ & 3 & 4 & 5 & 16 & 20 & 22 & 3 & 11 & 12 & 22 & 35 & 39 \\
\hline $\mathrm{N}+\mathrm{C}$ & - & - & - & 3 & 2 & - & - & - & - & 3 & 2 & - \\
\hline $\mathrm{N}+3 \mathrm{He}+\mathrm{H}$ & - & 2 & 1 & 5 & - & 3 & - & - & 2 & 5 & 2 & 6 \\
\hline $\mathrm{N}+2 \mathrm{He}+3 \mathrm{H}$ & 16 & 11 & 11 & 13 & 2 & 15 & 11 & 4 & 4 & 40 & 17 & 30 \\
\hline $\mathrm{N}+\mathrm{He}+5 \mathrm{H}$ & 16 & 38 & 19 & 13 & 8 & 17 & 13 & 11 & 9 & 42 & 57 & 45 \\
\hline $\mathrm{N}+7 \mathrm{H}$ & 8 & 5 & 4 & 8 & 18 & 11 & 3 & 6 & 16 & 19 & 29 & 31 \\
\hline $\mathrm{C}+\mathrm{B}+\mathrm{He}+\mathrm{H}$ & 3 & - & - & 3 & - & - & - & - & - & 6 & - & - \\
\hline $\mathrm{C}+3 \mathrm{He}+2 \mathrm{H}$ & 3 & - & 3 & 3 & - & 3 & - & - & 1 & 6 & - & 7 \\
\hline $\mathrm{C}+2 \mathrm{He}+4 \mathrm{H}$ & 8 & 5 & 18 & 8 & 9 & 16 & 8 & 4 & 6 & 24 & 18 & 40 \\
\hline $\mathrm{C}+\mathrm{He}+6 \mathrm{H}$ & - & 18 & 8 & 19 & 15 & 14 & - & 16 & 13 & 19 & 49 & 35 \\
\hline $\mathrm{C}+8 \mathrm{H}$ & - & 2 & 2 & - & - & 12 & - & 13 & 8 & - & 15 & 22 \\
\hline $\mathrm{B}+4 \mathrm{He}+\mathrm{H}$ & 2 & - & $=$ & - & - & - & - & - & - & 2 & - & - \\
\hline $\mathrm{B}+3 \mathrm{He}+3 \mathrm{H}$ & - & - & 3 & - & - & 5 & - & - & - & - & - & 8 \\
\hline $\mathrm{B}+2 \mathrm{He}+5 \mathrm{H}$ & 5 & 4 & 4 & 5 & 11 & 11 & 3 & - & 5 & 13 & 15 & 20 \\
\hline $\mathrm{B}+\mathrm{He}+7 \mathrm{H}$ & 3 & 15 & 4 & 3 & 13 & 18 & 3 & 7 & 10 & 9 & 35 & 32 \\
\hline $\mathrm{B}+9 \mathrm{H}$ & - & - & 2 & 3 & 7 & 7 & - & 4 & 9 & 3 & 11 & 18 \\
\hline $\mathrm{Be}+4 \mathrm{He}+2 \mathrm{H}$ & 3 & - & 1 & - & - & - & - & - & - & 3 & - & 1 \\
\hline $\mathrm{Be}+3 \mathrm{He}+4 \mathrm{H}$ & 2 & 2 & 2 & 3 & - & 1 & - & - & 2 & 5 & 2 & 5 \\
\hline $\mathrm{Be}+2 \mathrm{He}+6 \mathrm{H}$ & 3 & 5 & 6 & - & 2 & 5 & - & - & 3 & 3 & 7 & 14 \\
\hline $\mathrm{Be}+\mathrm{He}+8 \mathrm{H}$ & - & 4 & 6 & - & 14 & 8 & - & 15 & 9 & - & 33 & 23 \\
\hline $\mathrm{Be}+10 \mathrm{H}$ & - & - & 3 & - & 4 & 7 & - & 5 & 10 & - & 9 & 20 \\
\hline $\mathrm{Li}+5 \mathrm{HH}+\mathrm{e}$ & - & - & - & - & - & 1 & - & - & 0 & - & - & 1 \\
\hline $\mathrm{Li}+4 \mathrm{He}+3 \mathrm{H}$ & - & - & - & - & - & - & - & - & 2 & - & - & 2 \\
\hline $\mathrm{Li}+3 \mathrm{He}+5 \mathrm{H}$ & - & 4 & 2 & - & - & 1 & - & - & 2 & - & 4 & 5 \\
\hline $\mathrm{Li}+2 \mathrm{He}+7 \mathrm{H}$ & - & 2 & 5 & - & - & 5 & - & - & 6 & - & 2 & 16 \\
\hline $\mathrm{Le}+\mathrm{Hi}+9 \mathrm{H}$ & - & 4 & 3 & - & 4 & 6 & - & 6 & 11 & - & 14 & 20 \\
\hline $\mathrm{Li}+11 \mathrm{H}$ & - & 2 & 1 & - & 2 & 6 & - & - & 12 & - & 4 & 19 \\
\hline $6 \mathrm{He}+2 \mathrm{H}$ & - & - & 5 & 3 & 0 & 1 & - & - & - & 3 & - & 6 \\
\hline $5 \mathrm{He}+4 \mathrm{H}$ & 11 & - & 4 & 16 & 0 & 6 & - & - & 3 & 27 & - & 13 \\
\hline $4 \mathrm{He}+6 \mathrm{H}$ & 16 & 5 & 11 & 13 & 11 & 27 & 5 & 7 & 8 & 34 & 23 & 46 \\
\hline $3 \mathrm{He}+8 \mathrm{H}$ & 21 & 29 & 26 & 48 & 51 & 45 & 40 & 38 & 51 & 109 & 118 & 122 \\
\hline $2 \mathrm{He}+10 \mathrm{H}$ & 45 & 53 & 16 & 51 & 84 & 59 & 101 & 97 & 78 & 197 & 234 & 153 \\
\hline $\mathrm{He}+12 \mathrm{H}$ & 37 & 36 & 10 & 100 & 68 & 66 & 165 & 163 & 132 & 302 & 267 & 208 \\
\hline $14 \mathrm{H}$ & - & 18 & 3 & 64 & 66 & 60 & 237 & 295 & 227 & 301 & 379 & 290 \\
\hline $\mathrm{O}^{1}$ & - & 7 & - & 3 & 18 & 1 & 75 & 200 & 58 & 78 & 225 & 59 \\
\hline All & 430 & 413 & 422 & 726 & 585 & 717 & 785 & 943 & 802 & 1941 & 1941 & 1941 \\
\hline
\end{tabular}

${ }^{1}$ No fragments of projectile in the narrow forward cone (i.e, $Q=0$ )

Table 1. Topology normalized of the ${ }^{28} \mathrm{Si}$ fragmentation at 14.6 and $3.7 \mathrm{~A} \mathrm{GeV}$ (minimum bias). 


\section{RESULTS AND DISCUSSIONS}

According to the criteria for the separation and identification of the PFs, we show in Table 1, the topology for all events of the minimum biased sample obtained from the present work in comparison with the corresponding ones, for $\left(14.6 \mathrm{~A} \mathrm{GeV}{ }^{28} \mathrm{Si}[10]\right.$ and $3.7 \mathrm{~A} \mathrm{GeV}$ ${ }^{28} \mathrm{Si}$ ). Fig. 2 represents the topological diagram for the two silicon beams. It should be noticed that Fig. 2 includes the results of some channels observed in this work, which are not detected in Ref. [10]. All data are normalized to the same number of events. The topology seen in table1 represents all minimum biased events in which each channel includes the participants and the spectators of the Si beam. The participant part is represented by some or all of the H-fragments, so that the total charge in each channel should be 14 . On the other hand, Fig. 2 represents the charge distribution (spectators) of the Si beam with and without He PFs in comparison with the corresponding data of ${ }^{28} \mathrm{Si}(14.6$ and $3.7 \mathrm{~A} \mathrm{GeV})$ taken from [10] and [14], respectively.

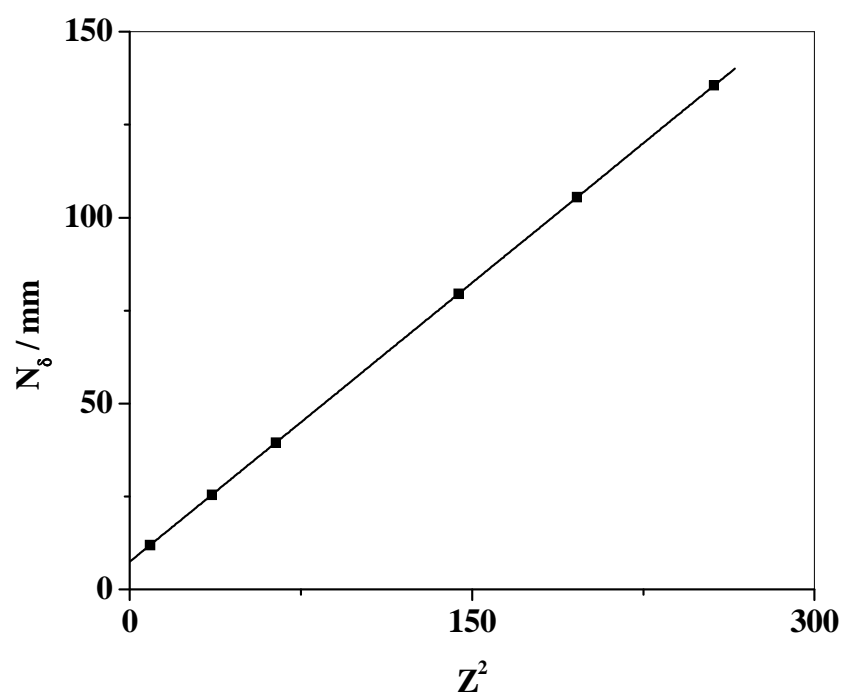

Fig. 1. Calibration line due to counting $\delta$-ray density $/ \mathrm{mm}$ using NIKFI-BR-2 nuclear emulsion irradiated by six primary beams $\left({ }^{4} \mathrm{He},{ }^{6} \mathrm{Li},{ }^{12} \mathrm{C},{ }^{16} \mathrm{O},{ }^{24} \mathrm{Mg},{ }^{28} \mathrm{Si}\right.$, and ${ }^{32} \mathrm{~S}$ at $3.7 \mathrm{~A}$ $\mathrm{GeV})$.

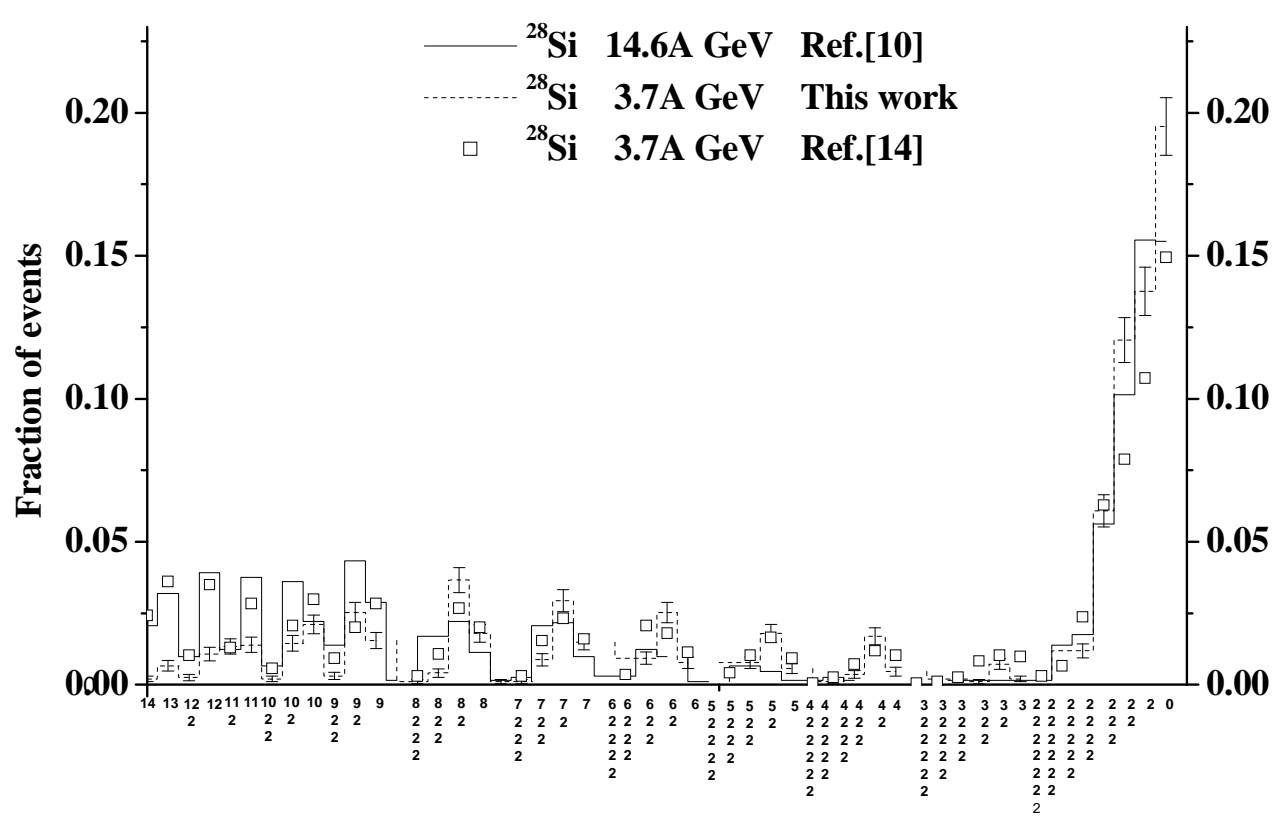

Fig. 2. Topological diagram for the total sample of events. The numbers below the $X$-axis represent the charge distribution of the spectators with and without $\alpha$-fragments.

The similarity of the three distributions obviously indicates that the beam energy is of little importance for the nuclear fragmentation process, except probably for the most peripheral interactions. Some evidence for a limiting fragmentation hypothesis is shown which implies that both projectile and target may be fragmented irrespective of each other, and that this fragmentation is independent on the beam energy.

Charge identification of relativistic multiply charged fragments has been made by measurements of the total number of $\delta$-rays per mm of the track near the star, and at least one point more than $1 \mathrm{~cm}$ from the star has been also measured.

The mean value of ( $\delta$-ray per $\mathrm{mm}$ ) readings was taken. In order to measure the charge of each PFs, a calibration curve is constructed by using $\delta$-ray of primary ${ }^{28} \mathrm{Si}$ beams and $\mathrm{He} \mathrm{PFs}$, chosen as charge references in addition to that of beams charge given in Fig. 3 .

According to the proportionality of the number of $\delta$-ray per $\mathrm{mm}\left(N_{\delta}\right)$ with $Z^{2}$ of the fragment, i.e. $\frac{N_{\delta} \text { for } \mathrm{Si}}{N_{\delta} \text { for } \mathrm{He}}=\frac{Z_{\mathrm{Si}}^{2}}{Z_{\mathrm{He}}^{2}}$, one is able to obtain the linear rela- 
tion expressed by $N_{\delta}=A+B Z^{2}$. The fitting parameters $A$ and $B$ are given in Table 2 characterizing the $\delta$-rays calibration of PFs due to the interactions of ${ }^{28} \mathrm{Si}$ (3.7 and 14.6A GeV) with emulsion nuclei.

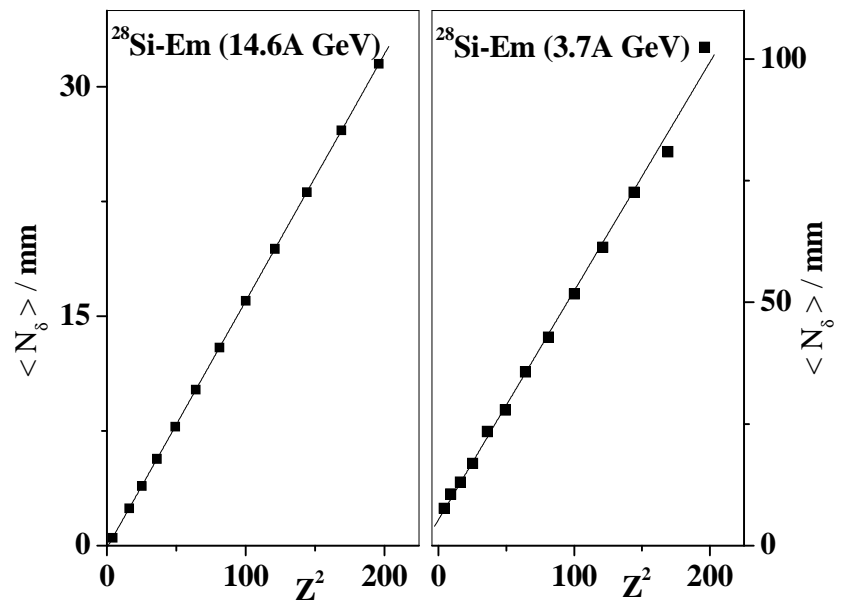

Fig. 3. The calibration lines for all projectile fragments $(Z=2-14)$ corresponding to the average values of $\delta$-ray per $\mathrm{mm}$ characterizing each fragmented track of charge $Z$ through the interactions of ${ }^{28} \mathrm{Si}(3.7$ and $14.6 \mathrm{~A} \mathrm{GeV})$ with emulsion nuclei.

\begin{tabular}{|c|c|c|}
\hline $\begin{array}{c}\text { Fitting } \\
\text { Parameters }\end{array}$ & ${ }^{28} \mathrm{Si}(3.7 \mathrm{~A} \mathrm{GeV})$ & ${ }^{28} \mathrm{Si}(14.6 \mathrm{~A} \mathrm{GeV})$ \\
\hline $\mathrm{A}$ & $5.37 \pm 0.90$ & $-0.15 \pm 1.74 \times 10^{-17}$ \\
$\mathrm{~B}$ & $0.47 \pm 0.01$ & $0.16 \pm 1.68 \times 10^{-19}$ \\
\hline
\end{tabular}

Table 2. The fitting parameters of the calibration curves identifying the PFs due to ${ }^{28} \mathrm{Si}-\mathrm{Em}$ interactions at 3.7 and $14.6 \mathrm{~A} \mathrm{GeV}$.

The $\delta$-rays frequency distributions (histograms) of relativistic projectile fragments having charge $Z=2-14$ emitted from ${ }^{28} \mathrm{Si}$ projectile at $3.7 \mathrm{~A} \mathrm{GeV}$ are given in Fig. 4 . The $Z=2$ histogram represents the $\delta$-rays measurements for 40 tracks produced in randomly chosen inelastic interactions. On the other hand, the $Z=14$ histogram indicate the results of the measurements for a sample of 30 tracks of ${ }^{28} \mathrm{Si}$ beam in addition to the primary projectile tracks having $Z=14$. A series of histograms were observed. Each of these histograms can be fitted by a Gaussian distribution with a peak corresponding to a certain value of $Z$, which can be determined by using the calibration line as illustrated by the associated arrow. For comparison Fig. 5 represents the corresponding results for PFs produced in $14.6 \mathrm{~A} \mathrm{GeV}{ }^{28} \mathrm{Si}$ interaction in nuclear emulsion [10].
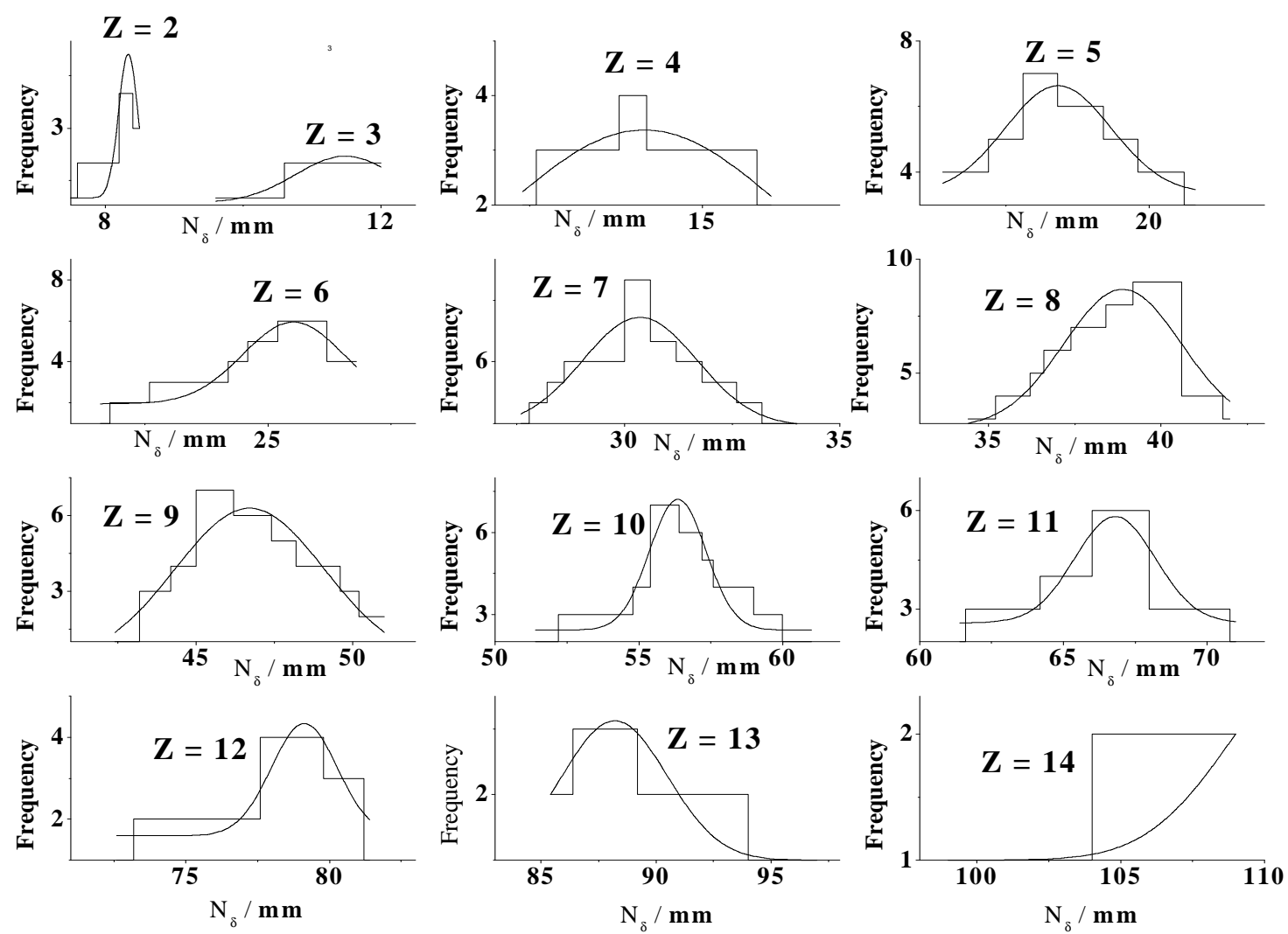

Fig. 4. The charge distributions of $\delta$-rays density/mm for secondary projectile fragments due to ${ }^{28} \mathrm{Si}(3.7 \mathrm{~A} \mathrm{GeV})$ interactions with emulsion (histograms) fitted by typical Gaussian (solid curves). 

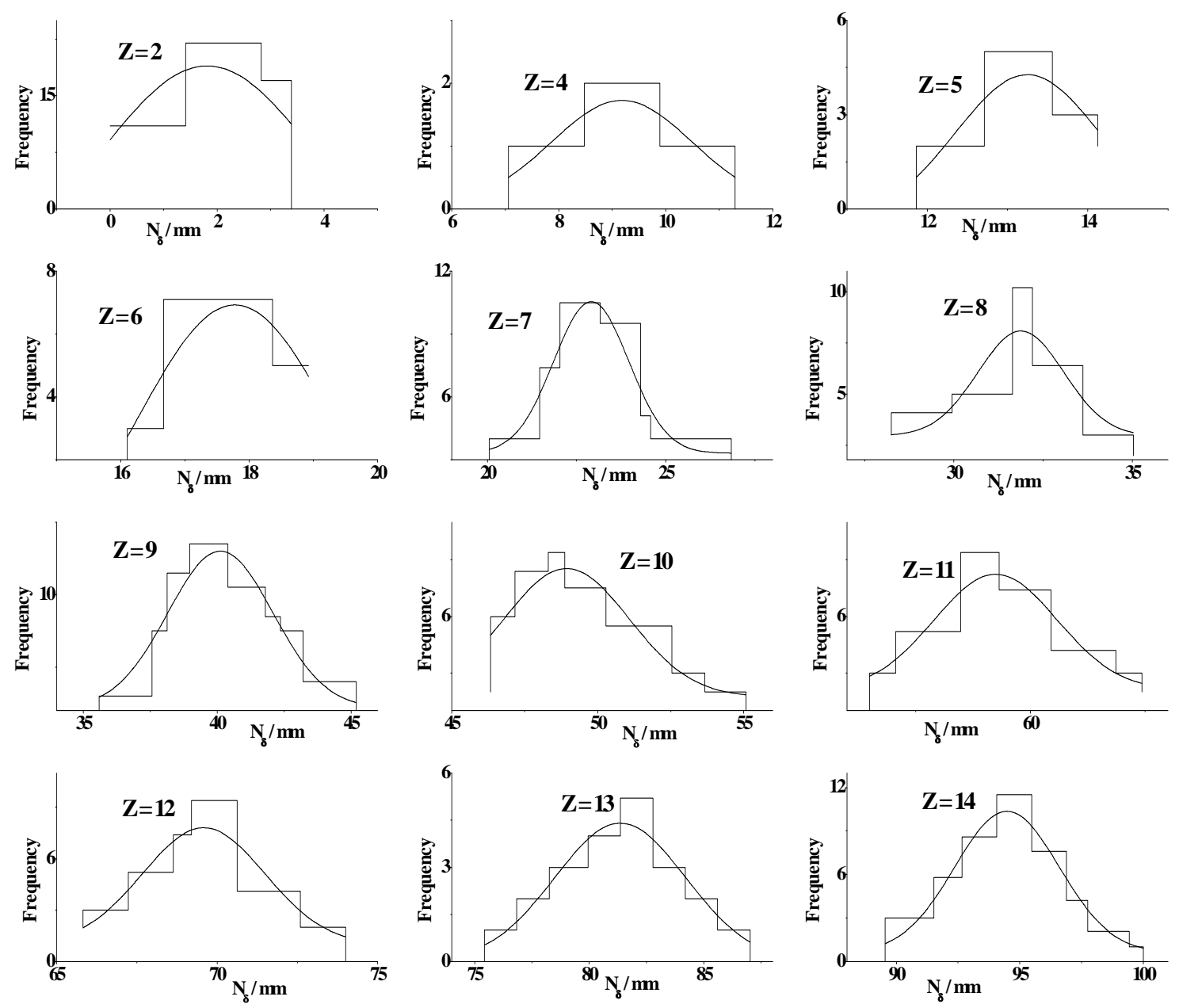

Fig. 5. The charge distributions of $\delta$-rays density $/ \mathrm{mm}$ for secondary projectile fragments due to ${ }^{28} \mathrm{Si}(14.6 \mathrm{~A} \mathrm{GeV})$ interactions with the emulsion nuclei (histograms) fitted by a typical Gaussian (solid curves).

The similarity of the two figures (Fig. 4 and Fig. 5) obviously indicates that the beam energy is of little importance for the nuclear fragmentation process.

\begin{tabular}{|c|c|c|}
\hline Charge & $\begin{array}{c}{ }^{28} \mathrm{Si}-\mathrm{Em}(3.7 \mathrm{~A} \mathrm{GeV}) \\
\left\langle N_{\delta}\right\rangle\end{array}$ & 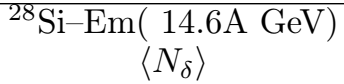 \\
\hline 2 & $7.66 \pm 0.05$ & $1.81 \pm 1.66$ \\
\hline 3 & $10.53 \pm 0.22$ & - \\
\hline 4 & $12.99 \pm 0.22$ & $9.18 \pm 0.43$ \\
\hline 5 & $16.88 \pm 0.14$ & $13.25 \pm 0.25$ \\
\hline 6 & $23.41 \pm 0.11$ & $17.78 \pm 0.34$ \\
\hline 7 & $27.85 \pm 0.14$ & $22.91 \pm 0.15$ \\
\hline 8 & $35.68 \pm 0.20$ & $31.88 \pm 0.43$ \\
\hline 9 & $42.85 \pm 0.15$ & $40.12 \pm 0.17$ \\
\hline 10 & $51.70 \pm 0.09$ & $48.96 \pm 0.31$ \\
\hline 11 & $61.29 \pm 0.33$ & $59.24 \pm 0.25$ \\
\hline 12 & $72.60 \pm 0.77$ & $69.58 \pm 0.33$ \\
\hline 13 & $80.92 \pm 0$ & $81.35 \pm 0.26$ \\
\hline 14 & $102.42 \pm 0$ & $94.48 \pm 0.20$ \\
\hline
\end{tabular}

Table 3. The average values of $\delta$-ray per mm characterizing each fragmented track of charge $Z$ through the interactions of ${ }^{28} \mathrm{Si}(3.7$ and $14.6 \mathrm{~A} \mathrm{GeV})$ with the emulsion nuclei.
Table 3 represents the average values of $\delta$-ray per mm characterizing each fragment track of charge $Z$ through the interactions of $3.7 \mathrm{~A} \mathrm{GeV}{ }^{28} \mathrm{Si}$ with the emulsion nuclei in comparison with those corresponding to the interaction of ${ }^{28} \mathrm{Si}$ at $14.6 \mathrm{~A} \mathrm{GeV} \mathrm{[10].}$

The dispersion $D_{\delta}$ of $\delta$-ray spectrum belonging to each charge is defined as $D_{\delta}=\sqrt{\left\langle N_{\delta}^{2}\right\rangle-\left\langle N_{\delta}\right\rangle^{2}}$.

In Fig. 6 the ratios of $D_{\delta} /\left\langle N_{\delta}\right\rangle$ versus $\left\langle N_{\delta}\right\rangle$ are displayed for silicon beams at both energies. The data (points) can be fitted by $2^{\text {nd }}$ order exponential decay of from, $D_{\delta} /\left\langle N_{\delta}\right\rangle=A_{1} e^{-\left\langle N_{\delta}\right\rangle / t_{1}}+A_{2} e^{-\left\langle N_{\delta}\right\rangle / t_{2}}$ and presented in the figure by the smooth curves. The fitting parameters $A_{1}, A_{2}, t_{1}, t_{2}$ are shown in Table 4 .

It is shown in Fig. 6 for ${ }^{28} \mathrm{Si}(3.7 \mathrm{~A} \mathrm{GeV})$ that $D_{\delta} /\left\langle N_{\delta}\right\rangle$ decreases strongly as an increase of $\left\langle N_{\delta}\right\rangle$ at small value of $\left(\left\langle N_{\delta}\right\rangle \sim 20\right)$ corresponding to light PFs ( $\left.\mathrm{He}, \mathrm{Li}, \mathrm{Be}\right)$. At larger values of $\left\langle N_{\delta}\right\rangle$, corresponding to $Z>4$, the ratio tends to saturate linearly. The ratio $D_{\delta} /\left\langle N_{\delta}\right\rangle$ for $\mathrm{Si}$ (14.6A GeV) seems to be gradually decreasing.

For PFs the behavior of the curves illustrated in Fig. 6 suggests that there is a positive long range correlation in emitting different charge nuclei from both silicon beams. 

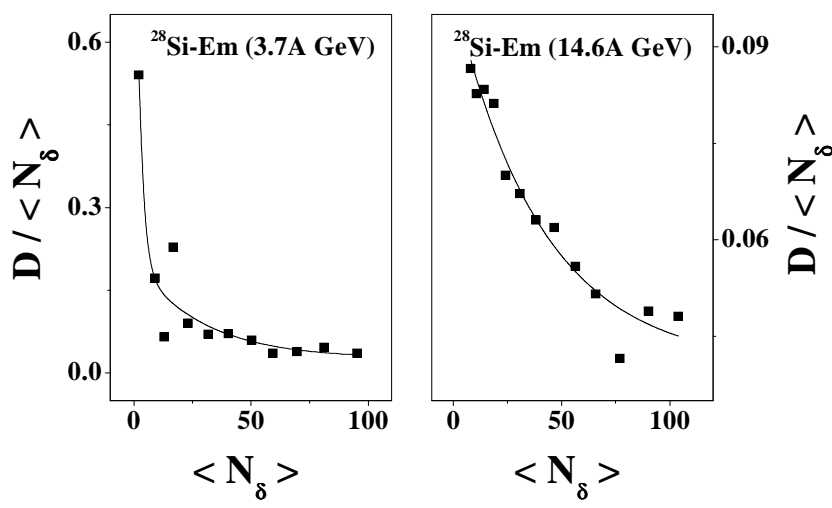

Fig. 6. The ratio $D_{\delta} /\left\langle N_{\delta}\right\rangle$ for the interactions of ${ }^{28} \mathrm{Si}(3.7$ and $14.6 \mathrm{~A} \mathrm{GeV}$ ) with the emulsion nuclei against the $\left\langle N_{\delta}\right\rangle$ belonging to each charge $\delta$-ray spectrum fitted by hyperbolic shaped curves.

\begin{tabular}{|c|c|c|}
\hline Projectile & ${ }^{28} \mathrm{Si}-\operatorname{Em}(3.7 \mathrm{~A} \mathrm{GeV})$ & ${ }^{28} \mathrm{Si}-\mathrm{Em}(14.6 \mathrm{~A} \mathrm{GeV})$ \\
\hline $\mathrm{A}_{1}$ & $-0.65 \pm 0.21$ & $1.37 \pm 8.78$ \\
$\mathrm{~A}_{2}$ & $0.06 \pm 0.02$ & $0.18 \pm 0.12$ \\
$t_{1}$ & $3.97 \pm 12.12$ & $1.56 \pm 7.55$ \\
$t_{2}$ & $34.39 \pm 17.38$ & $27.95 \pm 41.60$ \\
\hline
\end{tabular}

Table 4. The fitting parameters of the correlation between $D_{\delta} /\left\langle N_{\delta}\right\rangle$ versus $\left\langle N_{\delta}\right\rangle$ through the interactions of ${ }^{28} \mathrm{Si}$ (3.7 and $14.6 \mathrm{~A} \mathrm{GeV})$ with the emulsion nuclei.

Now the normalized distribution of $\delta$-ray densities $P\left(N_{\delta}\right) \%$, is done in its scaling presentation according to the two used energies (3.7 and $14.6 \mathrm{~A} \mathrm{GeV})$ of ${ }^{28} \mathrm{Si}$ beam. Hence, Fig. 7, represents a plot of $\psi(\xi)=\left\langle N_{\delta}\right\rangle P\left(N_{\delta}\right) \%$ as a function of the scaling parameter $\xi=N_{\delta} /\left\langle N_{\delta}\right\rangle$ for silicon beam at $(3.7$ and $14.6 \mathrm{~A} \mathrm{GeV})$. It is note worthy that all the data points for ${ }^{28} \mathrm{Si}(3.7 \mathrm{~A} \mathrm{GeV})$ and
${ }^{28} \mathrm{Si}(14.6 \mathrm{~A} \mathrm{GeV})$ [10] lie on a simple universal curve represented by a polynomial scaling law of the form, $\psi(\xi)=\sum_{i=0}^{3} a_{i} \xi^{i}$. The fitting parameter ai is listed in Table 5. Therefore, the universality in the scaling curve implies an energy independence in high energy projectile fragmentation regarded as limiting fragmentation hypothesis.

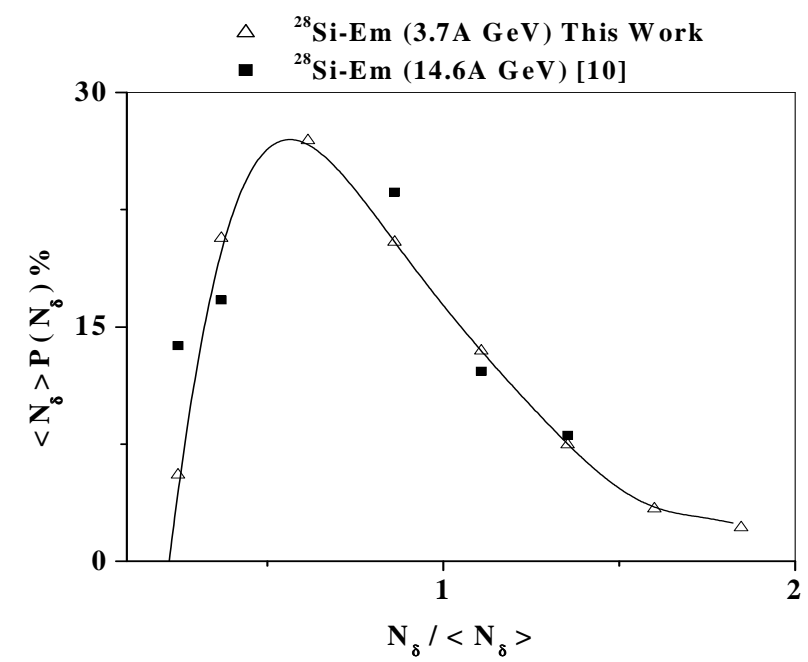

Fig. 7. The normalized multiplicity distributions of available values of $\delta$-ray densities associated with the charged projectile fragments due to the interactions of ${ }^{28} \mathrm{Si}$ (3.7 and 14.6A $\mathrm{GeV}$ ) with emulsion fitted by polynomial shapes.

\begin{tabular}{|c|c|}
\hline$a_{0}$ & $-51.015 \pm 6.987$ \\
\hline$a_{1}$ & $6.632 \pm 0.777$ \\
\hline$a_{2}$ & $-0.189 \pm 0.027$ \\
\hline$a_{3}$ & $0.002 \pm 0$ \\
\hline
\end{tabular}

Table 5. The parameters of the scaling law characterizing the energy independence for ${ }^{28} \mathrm{Si}$ fragmentation in nuclear emulsion.

\begin{tabular}{|c|c|c|}
\hline $\begin{array}{c}\text { No of Emitted } \\
\alpha \text { Particles }\end{array}$ & $\begin{array}{c}\text { Percentage of events associated with } \alpha \\
\text { and without heavy fragments }\end{array}$ & $\begin{array}{c}\text { Percentage of events associated with } \alpha \\
\text { and heavy fragments }\end{array}$ \\
\hline $1 \alpha$ & 15.34 & 21.16 \\
& $(15.24)$ & $(15.78)$ \\
\hline $2 \alpha$ & 27.09 & 8.68 \\
& $(19.79)$ & $(5.24)$ \\
\hline $3 \alpha$ & 20.63 & 1.59 \\
& $(16.44)$ & $(2.41)$ \\
\hline $4 \alpha$ & 5.5 & - \\
& $(6.95)$ & - \\
\hline $5 \alpha$ & - & - \\
\hline $6 \alpha$ & $(6.68)$ & - \\
\hline
\end{tabular}

Table 6. The normalized multiplicity of $\alpha$ particles, with and without heavy fragments, produced due to the interactions of ${ }^{28} \mathrm{Si}(3.7$ and $14.6 \mathrm{~A} \mathrm{GeV})$ with emulsion nuclei. 
Table 6 presents the salient features of primary peripheral events of ${ }^{28} \mathrm{Si}$ nuclei at $3.7 \mathrm{~A} \mathrm{GeV}$ in comparison with the ${ }^{28} \mathrm{Si}$ nuclei $14.6 \mathrm{~A} \mathrm{GeV}$ [10], yielding different hydrogen PFs multiplicities associated with and without heavy PFs of $Z>2$. The data of $14.6 \mathrm{~A} \mathrm{GeV}{ }^{28} \mathrm{Si}$ are placed between semi-circular parenthesis in Table 6 , while those of $3.7 \mathrm{~A} \mathrm{GeV}{ }^{28} \mathrm{Si}$ placed without parentheses. One can observe from the table that basically the data for ${ }^{28} \mathrm{Si}(3.7 \mathrm{~A} \mathrm{GeV})$ are in satisfactorily agreement with those of ${ }^{28} \mathrm{Si}(14.6 \mathrm{~A} \mathrm{GeV})$. The number of helium PFs per event produced are 1.81 and 2.17 for ${ }^{28} \mathrm{Si}(3.7 \mathrm{~A}$ $\mathrm{GeV})$ and ${ }^{28} \mathrm{Si}(14.6 \mathrm{~A} \mathrm{GeV})$, respectively. These numbers increase to 2.01 and 2.48 with no associated heavy PFs of charge $Z>2$ and decrease to 1.38 and 1.59 in the case of events associated with heavy PFs of $Z>2$. In all cases both data of silicon strongly reflect the presence of $\alpha$-clusters inside the silicon beam.

\section{CONCLUSION}

From this investigation we conclude the following:

1. The charge of each produced fragment is easily identified using $\delta$ ray measurements.
2. The yield of multiply charged fragments at 3.7A $\mathrm{GeV}$ is nearly the same as at $14.6 \mathrm{~A} \mathrm{GeV}$. This reflects the fact that the beam energy is of little importance for the nuclear fragmentation process at high energy.

3. There is a positive long range correlation in emitting different charges produced from the ${ }^{28} \mathrm{Si}$ beam at 3.7 and $14.6 \mathrm{~A} \mathrm{GeV}$.

4. The fragmentation of ${ }^{28} \mathrm{Si}$ nuclei in nuclear emulsion exhibits a limiting behavior which is achieved by the observed scaling in $\delta$-ray multiplicity at the two incident energies, although there is a considerable difference between 3.7 and $14.6 \mathrm{~A} \mathrm{GeV}$.

5. The number of helium fragments per event emitted in silicon beam interactions at the two energies strongly reflects the presence of $\alpha$-clustering inside silicon nuclei.

\section{ACKNOWLEDGEMENT}

The authors would like to thank all the staff of (Vekseler and Baldin) High Energy Laboratory at JINR, Dubna, Russia, for providing us the irradiated emulsion plates.
[*] M. El-Nadi High Energy Laboratory, Faculty of Science, Cairo University, Giza, Egypt.

[1] R. Stanoeva et al., Phys. At. Nucl. 72, 690 (2009).

[2] M. Karabová et al., Phys. At. Nucl. 72, 300 (2009).

[3] S. Cecchini et al., Nucl. Phys. A 807, 206 (2008).

[4] N. G. Peresadka et al., Phys. At. Nucl. 70, 1226 (2007).

[5] D. A. Artemenkov et al., Int. J. Mod. Phys. E 20, 993 (2011).

[6] M. S. El-Nagdy, Phys. Rev. C 47, 346 (1993).

[7] M. S. El-Nagdy, A. Abdelsalam, N. Ali-Mossa, A. M. Abdalla, S. M. Abdal-Halim, Khaled Abdel-Waged, Nucl. Phys. A 730, 419 (2004).

[8] M. El-Nadi, M. S. El-Nagdy, N. Ali-Mossa, A. Abdelsalam, A. M. Abdalla, S. M. Abdel-Halim, J. Phys. G 28, 1251 (2002).

[9] M. El-Nadi, M. S. El-Nagdy, A. Abdelsalam, E. A. Shaat, N. Ali-Mossa, Z. Abou-Moussa, Kh. Abdel-Waged, A. M-
Abdalla, E. El-Falaky, Eur. Phys. J. A 10, 177 (2001).

[10] M. El-Nadi, M. S. El-Nagdy, N. Ali-Mossa, A. Abdelsalam, A. M. Abdalla, A. A. Hamed, J. Phys. G 25, 1169 (1999).

[11] M. El-Nadi, M. S. El-Nagdy, A. Abdelsalam, E. A. Shaat, N. Ali-Mossa, Z. Abou-Moussa, Kh. Abdel-Waged, W. Osman, F. A. Abdel-Wahed, J. Phys. G 24, 2265 (1998).

[12] C. F. Powell, F. H. Fowler, D. H. Perkins, The Study of Elementary Particles by the Photographic Method, (Pergamon Press. London, New York, Paris, Los Angles, 1958) p. 474.

[13] M. S. El-Nagdy, A. Abdelsalam, E. A. Shaat, B. M. Badawy, E. M. Khashaba, Romanian J. Phys. 53, 487 (2008).

[14] S. A. Krasnov et al., JINR Report (Dubna), P1-88-252 (1988) [in Russian]. 


\section{ТОПОЛОГІЯ ФРАГМЕНТАЦІї ${ }^{28} \mathrm{Si}$ ЗА РІЗНИХ ЕНЕРІІЙ}

М. С. Ель-Нагді ${ }^{1}$, А. Абдельсалям ${ }^{2}$, Б. М. Бадаві ${ }^{3}$, А. Альгаоод ${ }^{4}$

${ }^{1}$ Факультет природничих наук, Гельвінсъкий університет, Гелъван, Єъипет

${ }^{2}$ Факультет природничих наук, Каїрсъкий університет, Гіза, Єәипет

${ }^{3}$ Цетр ядерних досліджень, Управління атомної енерл'ї, Єгипет

${ }^{4}$ Факультет природничих наук, Амрансъкий університет, Амран, Ємен

У статті описано виникнення фрагментів за нецентральних зіткнень $3.7 \mathrm{~A} \mathrm{GeV}{ }^{28} \mathrm{Si}$ у ядерній емульсії. Заряди цих фрагментів докладно виміряно й порівняно з отриманими з $3.7 \mathrm{~A} \mathrm{GeV}{ }^{28} \mathrm{Si}$. Наведено розподіл зарядів і їх апроксимацію за допомогою кривих Гаусса. Подано топологію фрагментації ${ }^{28} \mathrm{Si}$. Вивчено залежність фрагментації від енергії пучка, що падає. Досліджено наявність $\alpha$-кластера у кремнієвому пучку. 